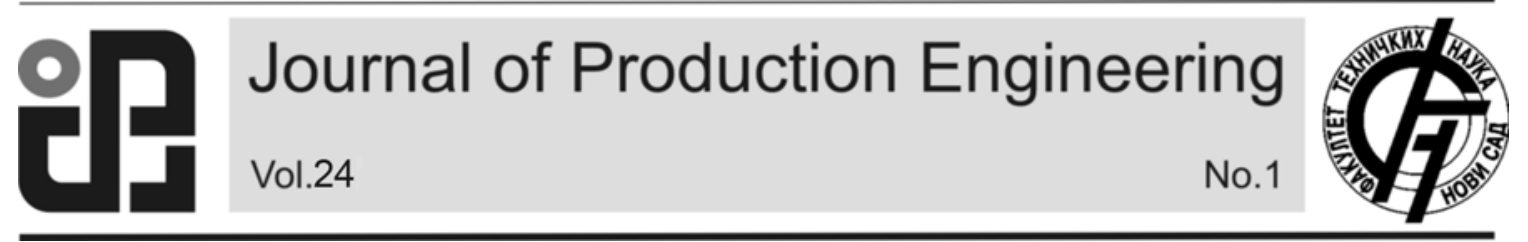

JPE (2021) Vol.24 (1)

Szentesi, Sz., Illés, B., Tamás, P.

Original Scientific Paper

\title{
MATHEMATICAL DESCRIPTION OF THE DISTRIBUTION LOGISTICS PROCESSES OF CONSIGNMENT SELLER DIETARY SUPPLEMENT MANUFACTURING COMPANIES
}

\author{
Received: 16 April 2021 / Accepted: 22 June 2021
}

\begin{abstract}
Consignment sales are a special case of supply chains, as the products are never the property of the seller, so the distribution logistics network and the logic of the structure of the products are radically different from those of normal supply chains. Another problem is that the products have a shelf life. The inventory mechanism $\left(q_{\min } ; q_{\max }\right)$ is most often used for the commissioned stocks of companies producing food supplements and when checking the central inventory, i.e. replenishment to the maximum stock level when a certain stock level is reached. There are several factors to consider when filling up commission stocks and reviewing them by period. With the mathematical correlations of these factors, it is possible to distribute the commissioned finished products optimally. The paper deals with this problem.
\end{abstract}

Key words: Consignment selling, inventory, shelf life.

Matematički opis distributivnih logističkih procesa preduzeća za proizvodnju I distribuciju dijetetskih suplemenata Konsignaciona prodaja je poseban slučaj lanaca snabdevanja, jer proizvodi nikada nisu vlasništvo prodavca, pa se distributivna logistička mreža i logika strukture proizvoda radikalno razlikuju od normalnih lanaca snabdevanja. Drugi problem je što proizvodi imaju rok trajanja. Mehanizam zaliha $\left(q_{\min } ; q_{\max }\right)$ najčešće se koristi za naručene zalihe kompanija koje proizvode suplemente prehrane i prilikom provere centralnog inventara, odnosno popunjavanje do maksimalnog nivoa zaliha kada se dostigne određeni nivo zaliha. Postoji nekoliko faktora koje treba uzeti u obzir prilikom popunjavanja zaliha i njihovog pregleda po periodima. Uz matematičke korelacije ovih faktora, moguće je optimalno distribuirati naručene gotove proizvode. Ovaj rad se bavi ovim problemom.

Ključne reči: Prodaja pošiljki, inventar, rok trajanja.

\section{INTRODUCTION}

In recent years, consumer demand for dietary supplements has increased significantly, so the product structure of dietary supplements is changing extremely rapidly and dynamically, based on customer needs. COVID also reached Europe in 2020, where sales figures for these products have grown dynamically [1]. The quickly changing and expanding product structure has significantly increased the quality and quantity requirements for logistics services related to companies manufacturing food supplements. Consignment sales have high expectations for the system of qualitative and quantitative requirements for logistics services [2]. Companies that manufacture food supplements and sell it on a consignment basis most often use the $\left(\mathrm{q}_{\min } ; \mathrm{q}_{\max }\right)$ inventory mechanism for their inventory, both in the central raw material and inventory warehouse and for consignment inventories. With the expansion of the product range manufactured and sold by companies, the complexity of production processes significantly increases [3], where the development and quality assurance of processes requires the development of innovative solutions, the development of which serves as the basis for many research topics. There are several factors to consider when replenishing consignment stocks and reviewing them by period. With the mathematical correlations of these factors, it is possible to distribute the consignor's finished products optimally. The dissertation describes the possibilities of the distribution of the finished product of the companies producing food supplements and selling them on a consigmnent basis, taking the changes that occur during distribution and due to the warranty period into account.

\section{MATHEMATICAL DESCRIPTION OF TYPICAL MATERIAL FLOWS}

The optimization of logistics systems is basically based on the mathematical description of material flows [4]. For optimization, I developed material flow matrices describing the practical problem.

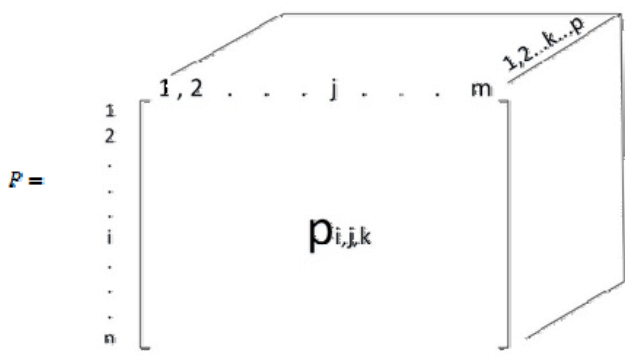

Fig. 1. Structure of the matrices used

In determining the material flow, I took into account the most important parameters, which are the following:

- location of material source,

- location of material inlet, 
- magnitude of material flow intensity,

- material flow rate in the given transport relation,

- type of material,

- start date of the material flow,

- the end date of the material flow.

The structure of the matrices I use is shown in Figure 1. Symbols used in Figure 1:

- $\quad \mathbf{P}(i, j, k)$ - matrix describing the tested material flow,

- $\mathrm{p}_{i, j, k}-$ the value of a parameter characterizing the tested material flow,

- $\quad i, j, k-$ index parameters that make the examined material flow value identifiable in space and time $(i=1,2 \ldots \mathrm{n}) ;(j=1,2 \ldots \mathrm{m}) ;(k=1,2 \ldots \mathrm{p})$.

Using such 3-dimensional matrices, I created the matrices necessary for the mathematical description of the investigated material flow problem.

These matrices are:

- matrix of customer order time ( $i$-th customer order date, from $k$-th consignee, of $j$-th product), T-matrix

- matrix of customer order quantities ( $i$-th customer, from $k$-th consignee, of $j$-th product) M-matrix,

- matrix of consignee's current stock quantities (how many stocks the $k$-th consignee has from $j$-th product) A-matrix,

- matrix of consignee's expected inventory demand quantity (for $k$-th consignee, how many $j$-th product were consumed in $l$-th period) $\mathrm{K}$-matrix,

- matrix for the expiration dates of consignee's product stocks (what is the shelf-life of the $k$-th consignee's inventory of the $j$-th product) S-matrix.

\section{MATRICES USED FOR MATHEMATICAL DESCRIPTION}

The matrices used are presented in this chapter, which are used for mathematical descriptions. The matrices are given in the form shown in point 2 .

\subsection{Matrix of customer order time}

Based on the matrix of customer order times, the following can be determined:

- $\quad$ the $i$-th customer,

- of a given product $(j)$,

- from a given consignee $(k)$,

- which date ordered to $\left(t_{i, j}, k\right)$.

Figure 2. shows an order time matrix that tells which product the customers ordered from the $k$-th consignee.

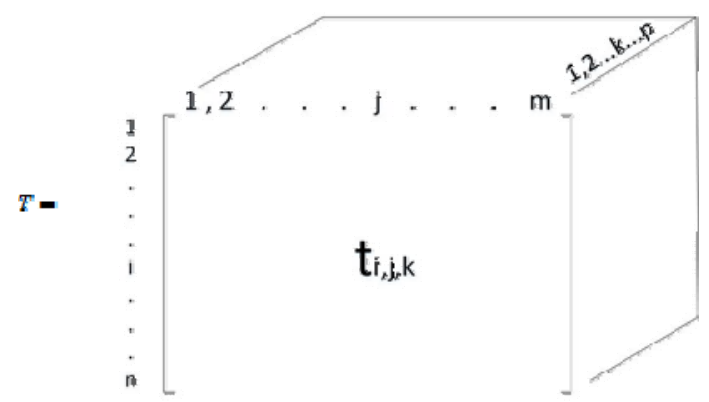

Fig. 2. Matrix of customer order time where:

$$
\text { - } T_{(\delta, t, k)} \text { - matrix of customer order time, }
$$

- $\quad t_{i, j, k}$ - order date of $i$-th customer, from $k$-th consignee, of $j$-th product.

\subsection{Matrix of customer order quantities}

Based on the matrix of customer order quantities, the following can be determined:

- $\quad$ the $i$-th customer,

- of a given product $(j)$,

- from a given consignee $(k)$,

- $\quad$ ordered what quantities $\left(\mathrm{m}_{\mathrm{i}, \mathrm{j}, \mathrm{k}}\right)$.

Figure 3. shows a matrix of sales order quantities, which contains the total number of products customers ordered from the $k$-th consignee.

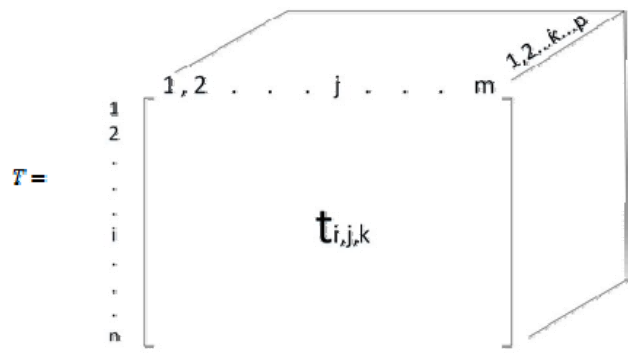

Fig. 3. Matrix of customer order quantities

where:

- $M_{(\delta, t, k)}$ : matrix of customer order quantities

- $\quad m_{i, k}:$ order quantity of $i$-th customer, from $k$-th consignee, of $j$-th product.

\subsection{Consignee' customer order matrix}

Using the matrices $\mathrm{T}$ and $\mathrm{M}$ defined in the previous section, we can determine the $k$-th consignee's customer's order quantity and time needs. From the matrices $\mathrm{T}$ and $\mathrm{M}$, the $K$-th two-dimensional sheets can be extracted. Let these be matrices $\mathrm{T}^{\mathrm{K}}$ and $\mathrm{M}^{\mathrm{K}}$ for $k=$ constant. The $k$-th consignee's time requirements are shown in Figure 4., while the quantity customer requirements are shown in Figure 5.

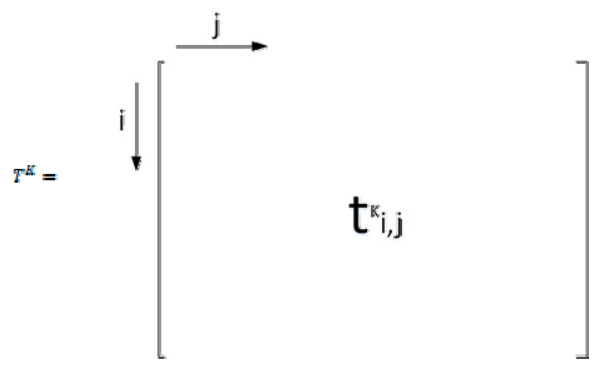

Fig. 4. Customer time requirements of the k-th consignee

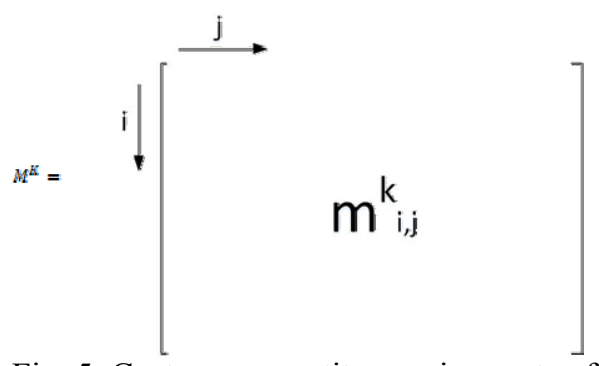

Fig. 5. Customer quantity requirements of the k-th consignee 
If the maximum number of consignees is $\mathrm{k}_{\max }$, then $\mathrm{k}_{\max }$ pieces of such a matrix can be formed.

\subsection{Matrix of consignee's current stock quantities} For commission customers, the following can be determined from the inventory records:

- $\quad$ at the $k$-th consignee,

- the $j$-th product's

- quantity $\left(a_{\mathrm{k}, \mathrm{j}}\right)$.

Figure 6. shows a matrix of consignees, which tells consignees' inventory of the $j$-th product

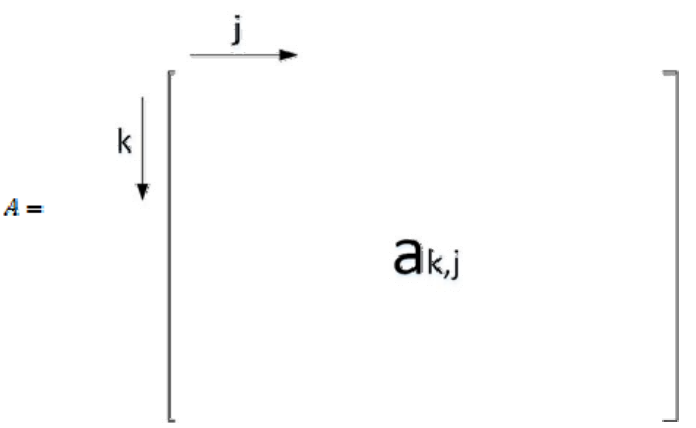

Fig. 6. Matrix of consignee's current stock quantities

where:

- $A_{(t, t, k)}$ - matrix of consignee's current stock quantities

- $\quad a_{k, j}-$ the $k$-th consignee's current stock of $j$-th product

\subsection{Matrix of consignee's expected inventory demand quantity}

When examining the placement of commission stocks the number of sales of a previous period must also be taken into account. For this reason, we need to examine the inventory of consignees one by one, product by product, taking into account sales for a dedicated period.

Based on the matrix of expected commission sales times, the following can be determined:

- $k$-th consignee,

- of $j$-th product,

- $\quad$ in $l$-th period,

- $\quad$ what quantity was sold $\left(\mathrm{k}_{k, j, l}\right)$.

The $k_{k, k, l}$ quantity must be multiplied by a SAFETY multiplication factor, since a certain number of additional safety stocks must be kept at the consignees. With this in mind, the matrix needs to be created.

Figure 7. shows a matrix of commission sales volumes, which tells us that how many $j$-th products were consumed in the $l$-th month at the $k$-th consignee. where:

- $K_{(k, \ldots, n)}$ - matrix of consignee's expected inventory demand quantity

- $\quad k_{k, j, l}-$ quantity sold of $j$-th products in the $l$-th period at the $k$-th consignee

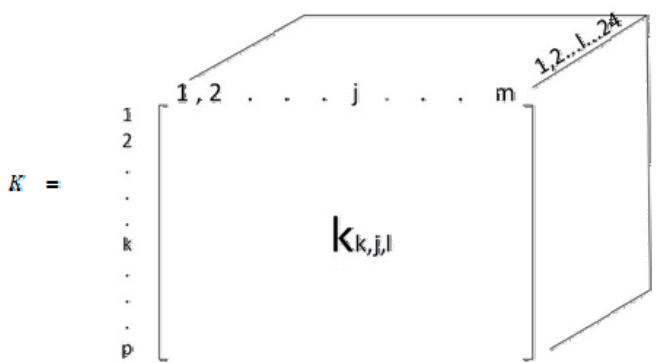

Fig. 7. Commission sales volume matrix

Since the consumption data are given on a monthly basis, the data of $k$-th consignee and $j$-th products can be interpreted on the basis of Figure 8 for $l=24$ months.

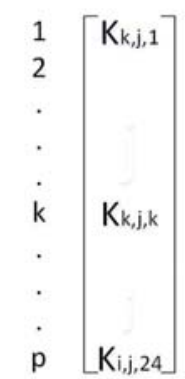

Fig. 8. Consumption data by product for a given period for a given consignee

\subsection{Matrix of consignee's expected inventory demand quantity}

In addition to taking into account the previous points, the shelf life of commission stocks must also be taken into account when examining the disposal, return or transfer. For this reason, the consignee's stock of finished products must be examined on a product-byproduct basis for shelf life.

The following can be determined on the basis of the consignee's product sehl life matrix:

- $k$-th consignee,

- $j$-th product,

- $f$-th shelf life (maximum 24 months),

- the quantity stocked $\left(\mathrm{s}_{k, j, f}\right)$.

Figure 9. shows the shelf life matrix of finished product stocks, which tells you the shelf lifes of $j$-th stocked products at the $k$-th consignee. For a simpler examination of the shelf life, the number of months that the product can still be used is entered into the matrix.

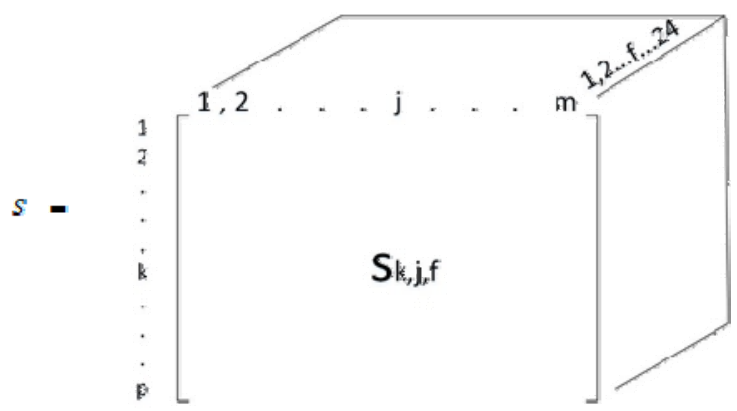

Fig. 9. Matrix for the expiration dates of consignee's product stocks 
where:

- $S_{(k, t, f)}-$ matrix for the expiration dates of consignee's product stocks,

- $\quad s_{k, j, f}-$ quantity of $j$-th product with $f$-th shelf life at $k$-th consignee.

- $1 \leq f \leq 24$; where $f$ value is given in months.

\section{MATHEMATICAL SUMMARY OF ALL} INVENTORY DEMANDS OF CONSIGNEES

Characteristic function for warranty period:

$$
\tau_{k, t, f}=\left\{\begin{array}{c}
0_{n} h a s_{k, t, f}>\beta_{n} \\
\mathbf{1}_{n} \text { else. }
\end{array}\right.
$$

Current expiring stock of the $j$-th product at the $k$-th consignee, taking into account the warranty periods:

$$
h_{k, f}=\sum_{f=0}^{24} s_{k, f, f} \cdot \tau_{k, b f}
$$

Reduced stock of the $j$-th product at the $k$-th consignee, taking into account customer orders and current stock:

$$
b_{k, t}=\sum_{i=1}^{n}-m_{i, j, k}+a_{k, t}
$$

Reduced stock of the $j$-th product at the $k$-th consignee, taking into account customer orders, warranty periods and current stock:

$$
c_{k, t}=b_{k, t}-h_{k, t}
$$

Quantity of $j$-th product the $k$-th consignee must currently have:

$$
\Delta_{k, t}=b_{k, t}-h_{k, t}-\sum_{i=n}^{m} k_{k, t, l}
$$

- if $\Delta_{k, t} \geq 0$; it does not need to be replenished, - if $\Delta_{k, 1} \leqslant 0 ;$ must be replenished.

The stock of $\mathrm{j}$-th product in the central warehouse on the basis of equations $(1,2,3,4,5)$ is required as determined by equation (6), assuming that the stocks held by the consignees can be returned to the central warehouse without restriction, their additional distribution is provided:

$$
\Delta_{t}=\sum_{k=1}^{p} \Delta_{k, t}
$$

- if $\Delta_{f} \geq q_{\mathrm{mn} f}$; then no production demand arises,

- if $\Delta_{f}<q_{m \mathrm{~m} f}$; then a production demand arises.
- $\quad \Delta_{j}-$ reduced stock size of $j$-th product for all suppliers.

$$
\left|\Delta_{f}\right| \rightarrow \min !
$$

\section{SUMMARY}

Based on the literature review and practical experience, I developed a model of the distribution logistics processes of companies manufacturing dietary supplement products, covering the components of the model, their functions and relationship system. Based on the created model, I determined its operating strategy. To implement the operational strategy, I developed a mathematical description of the real model, the associated decision models, and the definitions and descriptions of the matrices that support them. The results presented in the dissertation can be used for the practice primarily for more efficient performance of companies engaged in consignment sales. The developed model can also be used to review already commissioned inventories, which can provide an increasingly better application opportunity for the developed model, taking into account the sales data of recent years.

\section{REFERENCES}

[1] Jadwiga Hamulka , Marta Jeruszka-Bielak , Magdalena Górnicka, Małgorzata E. Drywie 'n and Monika A. Zielinska-Pukos *2021; Dietary Supplements during COVID-19 Outbreak. Results of Google Trends Analysis Supported by PLifeCOVID-19 Online Studies

[2] Coordination of a supply chain with consumerreturnundervendor-managed consignment inventory and stochasticdemand(Article), 2016 , Wu, Z.a,b, Chen, D.b, Yu, H.a

[3] Shraddha Mishra Surya Prakash Singh; 2020; Designing dynamic reverse logistics network for post-sale service; Annals of Operations Research.

[4] Dr. Cselényi József, Dr Illés Béla, 2006; Anyagáramlási rendszerek tervezése és irényítása I. könyv.

Authors: Assistant Lecturer Szabolcs Szentesi, University Professor Béla Illés PhD, Associate Professor Péter Tamás PhD, University of Miskolc, Faculty of Mechanical Engineering and Informatics, Institute of Logistics, Egyetemváros, 3515 Miskolc, Hungary, Phone.: +36 70 395-2007,

E-mail: altszabi@uni-miskolc.hu altilles@uni-miskolc.hu alttpeti@uni-miskolc.hu

where: 